\title{
The History of Dietetics
}

\author{
By Henry E. Sigerist
}

An unpublished manuscript

edited by André Blaser and Christoph Mörgeli

\section{SUMMARY}

Henry E. Sigerist's paper on the history of dietetics covers the entire development of dietetics since the emergence of the human species. Originating in early man's food-seeking instinct, dietetics had become an empirical science by the time of the ancient Greeks. They stressed the dietetic treatment of illness and began to formulate numerous rules. Regimina sanitatis, manuals containing precise dietetic prescriptions for the maintenance of good health, were widely circulated in the Middle Ages. In addition to new impulses initiated by Paracelsus, the author emphasizes the clinical and experimental studies pursued, from the 17th to the 19th centuries, by such scientists as Thomas Sydenham, Justus von Liebig, Carl von Voit and Gustav von Bunge. The author concludes by pointing out that, despite enormous progress, more than one half of the world's population still suffers from malnutrition. For this reason, he regards the social application of dietetic findings as the most urgent task facing us in the future.

\section{Editors' explanatory remarks}

Henry E. Sigerist (1891-1957) wrote "The History of Dietetics" in a blue, unruled notebook $(33 \times 21 \mathrm{~cm})$. It is now among Sigerist's remains at the Institute of Medical History of the University of Zurich.

The seventeen pages of his comprehensive study, which has not yet been published, appear at the end of the notebook (pp.19-36). Two different texts precede the one in question: The article "Die heilende Schweiz" (pp. 1-12), in German, was finished at Saragola Springs on 9 September 1941. This survey of the situation in Swiss medicine and its leading physicians was printed in a special edition of the journal "Die Schweiz" in 1943. Pages 13-18 of the notebook contain an English text entitled "Bombastic". It was written in Baltimore and is dated 20 November 1941. In this short text Sigerist points 
out the importance of Paracelsus Bombast von Hohenheim and examines the word "bombast" thoroughly by means of a linguistic analysis. This text appeared only a few days later (December 1941) on pages 688-689 of Sigerist's Bulletin of the Institute of the History of Medicine in Baltimore.

Unfortunately, the date as well as the indication of place do not appear in the third study entitled "The History of Dietetics". In view of the dates of the two previous articles, Sigerist can be supposed to have written it in his notebook at the turn of the year 1941/42.

\section{The text}

Instinctively man sought the food that his organism required. Civilisation began when he learned to make fire, which protected him against the cold, permitted him to make better tools and to cook his food. The greatest step in the history of civilisation was taken from the paleolithic to the neolithic period when man learned to grow the plants he wanted for food and learned to domesticate animals that would work for him and [provide] the meat of which he could eat. All over the world people spontaneously found a diet that sustained their organisms and was adapted to the climate. Instinct was also responsible for the discovery of special foods and drugs that cured or at least alleviated disease conditions_-just as animals are seen seeking certain herbs when they are ill. There is no sharp borderline between food and drug and it was soon found that foodstuffs consumed in unusual quantities or combinations had pharmacological effects. Dietetics became the science that studied the most appropriate mode of nutrition for the healthy and sick organism. It was for thousands of years a purely empirical science.

In antiquity the intake and choice of food was closely linked up with religious views - for obvious reasons. The acquisition of food was the driving force that compelled mankind to work. And the assimilation of food, the fact that dead animal and vegetable substance became part of the living body, appeared as a profound mystery. Dietary prescriptions are found in all ancient cults. Totem animals were hit to be eaten by members of the tribe. Vegetarianism appeared in India and in Greece, in the school of Pythagoras. Before meals the Greek and Roman sacrificed to the gods, the Christian said grace, and from the Greek Symposion to the Christian Agape, meals were taken in communion under observation of certain rites. Although food prescriptions such as we find in the Mosaic Code had a purely spiritual origin, 
they like other ancient rites had nevertheless important hygienic consequences.

While instinct was the first teacher of nutrition, a vast store of dietary experience was built up in the course of time and when a rational system of medicine developed in ancient Greece, physicians began to experiment with foods. In the view of the Alexandrians, Hippocrates, Praxagoras and Chrysippos were the three physicians who, in the 5th century B.C., had brought dietetics to perfection. And indeed the dietetic treatment of disease stood in the foreground of their therapeutic systems whereby the concept "diaita" had a broader implication than we assign it today. Diet to them was a man's entire mode of living, not only what he ate and drank but also sleep and being awake, work, exercise and rest, sex life and abstinence.

They believed that many diseases were the result of a wrong mode of living which upset the normal balance of the organism. The logical consequence was to treat them by prescribing a corrective diet that would help the natural healing power of the organism in restoring its balance. They wrote many books on the subject in which they discussed the effects of the various meats, vegetables, fruits, cereals, milk products, wines and other foodstuffs on the healthy and diseased body. Their views were gained empirically, to be sure, but their experience was based on keen observation. They did not know that certain wines form the Peloponnesus contain much tannic acid but they had observed their constringent effect and knew when to prescribe them.

Experience taught them that patients with high fever fare better on a liquid diet; they prescribed ptisane, a cream of barley. This and many similar rules were generally accepted and they have been followed for over 2000 years.

Other Greek medical schools held different theoretical views, but dietetics played an important part in all of them. Thus the methodicists, who ascribed all disease conditions to abnormal relaxation or constriction, emphasized physical therapy but combined it with dietary treatment. Greek dietary prescriptions were followed throughout the Middle Ages and were sometimes modified in accordance with local food habits. In the early 6 th century Theoderic's court physician Anthimos wrote a treatise on diet for the Frankish King Theoderich in which a prominent part was given to the use of bacon, a food that was very popular among the Franks *. All monastic

* Anthimus, a Byzantine physician, was sent by his master Theoderic I (the Great), King of the Ostrogoths 493-526, as an ambassador to the Frankish King of the same name. [Editors' note]. 
rules had articles regulating the periods of work and rest, prescribing the number of meals and of dishes, frequently with special regulations concerning friars of weak constitution. Regimina sanitatis were written for persons of high rank advising them how to live in order to preserve their health. They all contained detailed dietary prescriptions. Most famous among them was the Regimen sanitatis salernitanum. Composed in the 13 th century in verse it was copied and printed many times and is, with its numerous commentaries, one of our chief sources of dietetic lore for over five centuries.

Mediaeval dietetics was not original but consisted mostly of ancient reminiscences transmitting the results of Greek experience. A new departure was made in the Renaissance, particularly by Paracelsus, who endeavored to explain the phenomena of health and disease in terms of chemistry. It was a correct approach, but chemistry and physiology were not sufficiently advanced to permit a scientific exploration of nutrition. Paracelsus' concepts of sulphur, mercury and salt as the basic constituents of the human body had more symbolic than scientific value. A brilliant physician, he undoubtedly improved the dietetic treatment of certain diseases, but he did it empirically.

More important than general speculations were some clinical studies undertaken in the period from the 17th to the early 19th[!] centuries. A classical example is Thomas Sydenham's treatise on gout published in 1683 . Gout was widespread in England at that time, and Sydenham himself was a sufferer from it so that he had ample opportunity to experiment on his own body. He recommended moderation in eating and drinking, only one dish a meal, avoidance of liquor and wine, plenty of exercise.

In 1863 an English businessman, William Banting, published a Letter on Corpulence, the first two editions of which were sent free of charge to whoever asked for it. In it the author described a diet by which he had reduced his weight from 202 to 156 pounds in one year's time. The diet had been recommended to him by his physician Dr. John Harvey and he was so enthusiastic about the result that he wanted his fellow sufferers to benefit by his experience. The diet consisted chiefly of meat, reducing starches and fats to a minimum. The pamphlet was significant in that it not only described the recommended foods but gave accurate measures. His success all over the world was such that «banting» became a technical term, synonymous with «reducing». Yet the treatment was purely empirical and [when] applied indiscriminately could be very harmful.

Chemistry had its great revolution at the end of the 18th century when 
Lavoisier described the process of oxidation and introduced quantitative methods into chemistry. On the basis of his discoveries biochemistry developed and a new scientific approach could be made to the phenomena of digestion and metabolism. The French physiologist Magendie (1783-1855) studied experimentally the nutritive effects of the basic food substances proteins, carbohydrates and fats. His pupil Claude Bernard (1813-1878) discovered glycogen and the mechanism by which the liver is able to store glycose. In Germany, the chemist Justus von Liebig (1803-1873) became the pioneer of the new science of nutrition. He differentiated between foods that serve to replace used up proteins in the tissues and such that serve primarily as source of heat. He established calorie values of different foodstuffs and his work had a far-reaching influence on agriculture and cattle breeding.

While agriculturists readily accepted the results of the new physiological chemistry, there was a strange reluctance to apply them to human nutrition. Some people argued that the human race had survived for hundreds of thousands of years and had thrived without any knowledge of calories. Some men found it degrading to draw close parallels between animals and man. Yet sound practical considerations called for nutritional standards. When food prices were rising it was important to know which were the most economical foods. Standards were also needed for the feeding of soldiers and of the inmates of hospitals and other institutions. A student of Liebig, Carl Voit (1831-1908) took up these studies and developed a strong school at the University of Munich. Together with Pettenkofer, he investigated the relation between nutrition, respiration and metabolism in a chamber specially devised for the purpose. He demonstrated the nitrogen equilibrium, and our present knowledge of many basic facts is derived from his studies. His student Max Rubner (1854-1932) carried them still further, discovered the isodynamic law according to which carbohydrate and fat were interchangeable, and established the energy doctrine which viewed nutrition and metabolism from the standpoint of the energy requirement and consumption of the organism.

During those heroic years of nutritional science, attention was concentrated on quantities of foodstuffs while their qualities were frequently disregarded. A diet was considered adequate if it had a sufficient caloric value and included a certain minimum of proteins. It went so far that an American student of Voit, W.O. Atwater considered fresh fruit and vegetables an uneconomical luxury. Yet experience was teaching that animals fed on pure proteins, carbohydrates and fat did not grow and could not 
remain healthy even if minerals and water were given in sufficient quantity. This was first demonstrated experimentally on rats by von Bunge (1844-1920). It seemed, therefore, that the organism required some accessory substances which, without providing energy yet, were necessary for normal life. Studies on beriberi and some other diseases such as scurvy, rickets and pellagra which were recognized to be deficiency diseases led to the discovery of the vitamins, a discovery that revolutionized dietetics. It explained old experiences, man's desire for fresh fruit and vegetables or the fact that from the 17th[!] century on scurvy, the curse of navigation was prevented when oranges, lime juice or similar foods were available.

The new science of nutrition made it possible to determine what an adequate diet should be in quantity and quality. The new nutritional standards were particularly important in such countries as the Soviet Union where millions of people are fed from central factory kitchens. There, probably more than anywhere else, science has been able to change old food habits.

Nutritional science combined with pathological physiology also permitted to direct the dietetic treatment of patients along more scientific lives than in the past. Weir-Mitchell's cure of rest and exercise feeding for nervous exhaustion, the tuberculosis diets of H. Brehmer, P. Dettweiler and K. Turban, the diets of C. von Noorden for diabetes, nephritis and diarrhoea, B. W. Sippy's for gastric and duodenal ulcers, to mention only a few, were all clinical applications of the results of the new science. And in pediatrics it revolutionized the feeding of infants in health and disease.

Despite the tremendous progress achieved in dietetics there are still famines in the world and it is a safe estimate that over one half of the population of the globe suffers from malnutrition. Here, as in every other field, technology has outrun sociology; and the social application of the results of nutrition on a large scale is one of the most urgent tasks of the future. 


\section{Bibliography}

Chittenden, Russell H. The Development of physiological chemistry in the United States. New York, 1930.

Hintze, K. Geographie und Geschichte der Ernährung. Leipzig, 1934.

Lichtenfelt, H. Die Geschichte der Ernährung. Berlin, 1913.

Lusk, Graham. Nutrition. New York, 1933 (Clio medica, 10).

Marcuse, Julian. Diätetik im Altertum. Stuttgart, 1899.

Noorden, Carl von. Entwicklung und weitere Aufgaben der diätetischen Therapie. 1937.

\section{Zusammenfassung}

\section{Die Geschichte der Diätetik}

Henry E.Sigerists Aufsatz zur Geschichte der Diätetik gibt einen kurzen Überblick über die Entwicklung der Diätetik seit Beginn der Menschheit. Vom instinktiven Suchen nach der geeigneten Nahrung in der Frühzeit entwickelte sich die Diätetik zur empirischen Wissenschaft bei den Griechen. Diätetische Behandlungen von Krankheiten standen bei ihnen im Vordergrund, so daß unzählige Regeln aufgestellt wurden. Regimina sanitatis, Bücher mit genauen diätetischen Anweisungen zur Erhaltung der Gesundheit, fanden im Mittelalter weite Verbreitung. Neben den Gedankenanstößen von Paracelsus betont der Autor die Wichtigkeit der klinisch-experimentellen Studien von Forschern wie Thomas Sydenham, Justus von Liebig, Carl von Voit und Gustav von Bunge in der Zeit vom 17. bis 19. Jahrhundert. Der Aufsatz schließt mit dem Hinweis, daß trotz enormer Fortschritte noch mehr als die Hälfte der Weltbevölkerung an Unterernährung leiden müsse. Deshalb erachtet Henry E.Sigerist die soziale Anwendung der diätetischen Erkenntnisse als dringendste Aufgabe für die Zukunft. 


\section{Résumé}

\section{L'histoire de la diététique}

Cette contribution de Henry E. Sigerist à l'histoire de la diététique donne un court aperçu du développement de la diététique depuis les débuts de l'humanité. De quête instinctive de la nourriture appropriée qu'elle était à l'origine, la diététique s'est développée chez les Grecs en une science empirique. Le traitement diététique des maladies était chez eux au premier plan, de sorte que des règles innombrables furent établies. Les régimes de santé (regimina sanitatis), ouvrages présentant des prescriptions diététiques détaillées pour le maintien de la santé, connurent au Moyen Âge une vaste diffusion. A côté des réflexions stimulantes de Paracelse, l'auteur met l'accent sur l'importance des études cliniques menées entre le $17^{\mathrm{e}}$ et le $19^{\mathrm{e}}$ siècles par des chercheurs comme Thomas Sydenham, Justus von Liebig, Carl von Voit et Gustav von Bunge. Pour conclure, l'auteur rappelle que malgré les immenses progrès accomplis, plus de la moitié de la population mondiale souffre encore de malnutrition. Aussi considère-t-il l'application sociale des connaissances diététiques comme une tâche impérative dans l'avenir.

cand. phil. André Blaser

Semesterassistent, Medizinhistorisches Institut der Universität

Rämistraße 71

CH-8006 Zürich

Dr. phil. Christoph Mörgeli

Konservator, Medizinhistorisches Museum der Universität

Rämistraße 71

CH-8006 Zürich 